\title{
ACRL continuing education courses at ALA Annual Conference in New Orleans
}

The Association of College and Research Libraries will sponsor six continuing education courses at the ALA Annual Conference in New Orleans this summer. The courses are designed to provide academic librarians an opportunity to enhance their professional development, acquire new knowledge and skills, and update existing competencies. ACRL continuing education courses are taught by library practitioners well known for their expertise in specific areas.

The courses will be given in the New Orleans Convention Center on Friday, July 8, immediately before ALA Annual Conference. Refreshments will be provided at breaks, but participants will be responsible for their own lunches.

ACRL members receive a $30 \%$ discount on fees.

Written notice of cancellation received by June 10,1988 , will be honored subject to a $\$ 15$ cancellation charge. No refunds for cancellations will be given after June 10. ACRL is not responsible for any airfare penalties incurred as a result of a course being canceled.

A certificate of completion for each course will be issued. Every successful completion of 10 hours of continuing education is equal to one Continuing Education Unit (CEU). ACRL maintains a CEU record for each participant.

There are two ways to register: 1$)$ to register by phone, call (800) 545-2433-in Illinois, (800) 5452444-or (312) 944-6780;2) to register by mail, complete the registration form and return it to ACRL.

Confirmations will be sent with information about the location.

Multiple Registration Discount for staff from the same institution and registering at the same time. The first course (higher-priced course) will be the regular price, with additional registrations $20 \%$ off. Please photocopy the form for multiple registrations.

Please share this with a colleague!

If you have any questions contact ACRL/ALA, 50 East Huron St., Chicago, IL 60611-2795; or call (800) 545-2433.

\section{CE 111-Principles of Strategic Planning IN THE LibRARY ENVIRONMENT}

Would you like to have a clear picture of where your library will be next year or in five years? Strategic planning can give you that edge. Get practical experience as well as the theoretical background for applying the strategic planning process to your library planning. This course examines background information on strategic planning as a process, identifies problems encountered with past long-range planning efforts, describes several strategic planning models including the "desired futures" model. You will have an opportunity to practice the use of the desired futures model cooperatively and apply it to your own environment and receive valuable feedback on that experience. This course is applicable to strategic planning for all types of libraries.

Instructor: Julie Virgo, The Carroll Group.

Date: Friday, July 8, 1988, 9:00 a.m.-5:00 p.m.

Fee: ACRL members, \$95; non-members, $\$ 135$.

CEU Credit: .7.

Limited to first 30 registrants.

\section{CE 206-Creative Approaches to Video FOR BIBLIOGRAPHIC INSTRUCTION}

Over 600 libraries are currently producing videotaped bibliographic instruction, and many are of inferior quality. Become a discriminating producer of videos, explore their effective uses, become familiar with critical production issues, and make financial comparisons of various media products. Many examples of library video products will be examined. In addition, creative problem-solving techniques will be applied to the process of developing a videotape project.

Instructor: Thomas McNally, Ohio State University.

Date: Friday, July 8, 1988, 9:00 a.m.-5:00 p.m.

Fee: ACRL members, \$95; non-members, \$135.

CEU Credit: .7.

Limited to first 30 registrants.

\section{CE 209-Advanced Business Literature}

Understand the "bulls" and "bears" in this difficult market. Can you answer your clients' questions pertaining to market data, marketing/advertising, finance, and career options? At the end of this course you will be able to identify specialized business reference tools, select appropriate bibliographic instruction techniques for business students, and provide online search strategies that are critical to effective use of business databases.

Instructor: Charlotte Cubbage, consultant.

Date: Friday, July 8, 1988, 9:00 a.m.-5:00 p.m.

Fee: ACRL members, $\$ 95$; non-members, $\$ 135$.

CEU Credit: .7.

Limited to first 30 registrants.

\section{CE 302-Preparing Contracts and Negotiating with Library Automation Vendors}

Everything that you always wanted to know about contracts but were afraid to ask. Directors, middle managers, supervisors, and automation librarians will learn: the roles of each member in the 
contract negotiation process; how to describe procurement procedures that produce controlled negotiation environment; how to identify "classic" ploys and techniques used by vendors; how to prepare negotiation procedures to gain maximum advantage; how to build a checklist of content and performance issues to include in the instrument. This course is co-sponsored by the ALA Library Administration and Management Association.

Instructor: Robert Walton, Texas State Library.

Date: Friday, July 8, 1988, 9:00 a.m.-4:00 p.m.

Fee: ACRL or LAMA members, $\$ 75$; nonmembers, $\$ 110$.

CEU Credit: .55.

Limited to the first 50 registrants.

\section{CE 401-Libraries and Computer Centers: Cooperation or Separation?}

Know how your peers are handling the changing relationship of academic libraries and computer centers! This is an opportunity for library directors and associate directors to examine the changes taking place through speaker presentations, panel dis- cussion, and group interaction. Analyze organizational, functional and technological similarities and differences between these two units, including a historical perspective, while considering implications for the future of your institution. Learn what the political and organizational implications are of merging (or not merging) libraries with computer centers, and prepare yourself to address such change. Discuss with the leaders in this field, the financial impact, staffing, missions of the library and computing center, and the impact of a rapidly developing information technology base.

Instructor: Diane Cimbala, The Faxon Company.

Date: Friday, July 8, 1988, 9:00 a.m. $-5: 00$ p.m. Fee: ACRL members, $\$ 75$; non-members, $\$ 110$. CEU Credit: .7.

Limited to the first 50 registrants.

\section{CE 507-Basics of Statistics}

Do you think that statistics would be easier to understand if it used fewer numbers and more words? Actually, mastering the terminology of a

\section{Registration Form}

YES, I want to plan for success. Register me for the following courses(s):

\begin{tabular}{|l|l|l|}
\hline CE Number & Course Title & Course Fee \\
\hline & & \\
\hline & & \\
\hline
\end{tabular}

Name (write name as it should appear on badge)

Title Institution

Address City State Zip

Please check one: ACRL Member (Member Number Non-member

Payment Information Yes, we will take advantage of the multiple registration discount of $20 \%$. All registration forms are enclosed.

Total Course Fee(s) \$

Check enclosed

Please bill me
Charge my account

— Visa _ American Express

Signature

Acct. \# Exp.

Mail to: ACRL-Continuing Education, 50 East Huron Street, Chicago, Illinois 60611-2795. 
discipline is often more difficult than understanding the essential concepts. This course is intended for librarians with little or no mathematical or statistical training. It will help you to understand terminology, statistical concepts, and basic statistical measures. Don't let such words as sample and standard deviation prevent you from understanding the essentials of statistics.

Instructor: Timothy F. Richards, Vanderbilt University.

Date: Friday, July 8, 1988, 9:00 a.m. $-5: 00$ p.m.

Fee: ACRL members, $\$ 95$; non-members, $\$ 135$.

CEU Credit: .7.

Limited to the first 30 registrants.

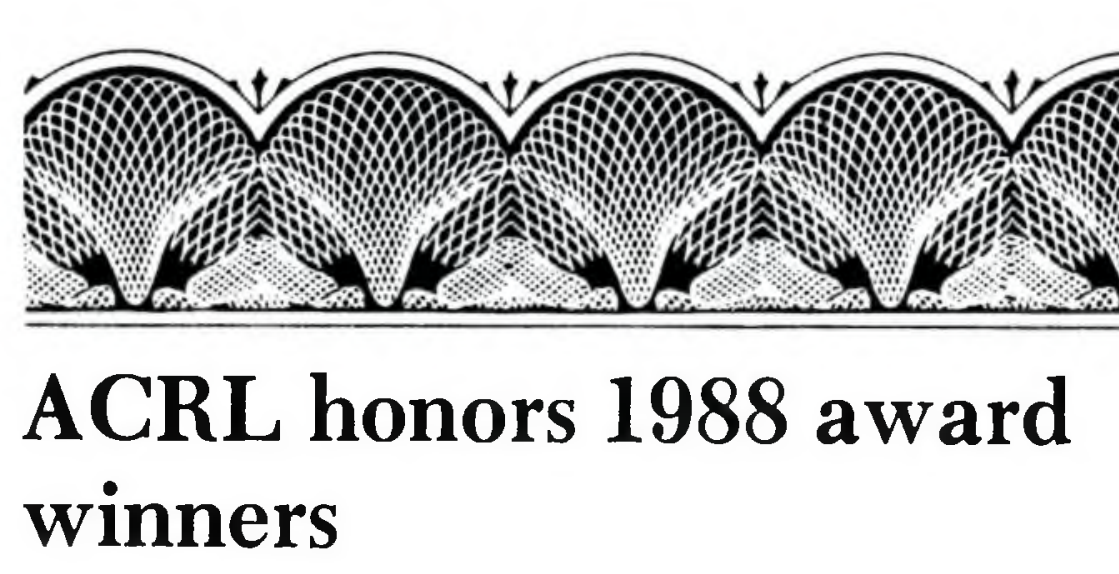

The Association of College and Research Libraries will honor the recipients of all its 1988 awards at the ALA Annual Conference in New Orleans. All the winners were selected by separate award juries. Four of the awards - the Baker \& Taylor Academic or Research Librarian of the Year, the two Institute for Scientific Information Fellowships, and the K.G. Saur College of Research Libraries awards-will be presented at the close (approximately 5:00 p.m.) of the ACRL President's Program on Monday, July 11. You are welcome to join us there in honoring these outstanding individuals.

The deadline for the 1989 awards is December 1, 1988. Information about nominations and applications for the 1989 awards may be obtained from Mary Ellen Davis, ACRL Program Officer, ACRL/ALA, 50 E. Huron Street, Chicago, IL 60611-2795; (312) 944-6780, x287.

\section{Academic or Research Librarian of the Year Award}

Edward Gailon Holley, of Chapel Hill, North Carolina, has been chosen to receive the $\$ 3,000 \mathrm{Ac}-$ ademic or Research Librarian of the Year Award. Holley will receive the award on July 11 at the ACRL President's Program in New Orleans. ACRL President Joanne Euster will present the cash award and citation, which are donated by the Baker and Taylor Company.

In naming Holley to receive the award, Donna M. Goehner, chair of the award jury, said, "Dr. Holley was se-

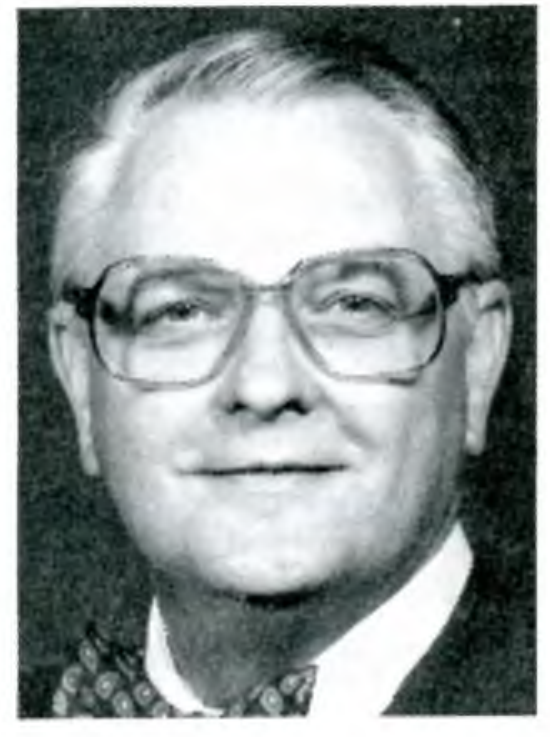

Ed Holley consulting activities.

"His has been an exemplary career, and throughout he has served as a role model and mentor for academic librarians. Dr. Holley has without question distinguished himself in virtually every major area of our library profession."

Holley, who received his doctorate from the University of Illinois, served as professor and dean at the School of Information and Library Science, University of North Carolina at Chapel Hill, from 1972 to 1985 . For nine years prior to that he was director of libraries at the University of Houston. A past president of ALA, Holley has also received the prestigious Melvil Dewey Medal and the Joseph W. Lippincott award for notable achievement in librarianship.

The citation commends Holley for his outstanding achievements and describes him as a "Renaissance librarian-a man of many talents ranging from excellent administrator and inspiring teacher to conscientious researcher and effective speaker and writer."

The ACRL Academic or Research Librarian of the Year Award is presented annually to recognize a member of the library profession who has made an outstanding national or international contribution to academic or research librarianship and library development.

Recipients of the award since its inception in 1978 have been Keyes D. Metcalf and Robert D. Downs (1978); Henriette D. Avram and Frederick G. Kilgour (1979); Evan I. Farber (1980); Beverly P. Lynch (1981); William Budington (1982); Richard M. Dougherty (1983); Richard Johnson (1984); Jessie Carney Smith (1985); Margaret Beckman (1986); and Duane Webster (1987). 